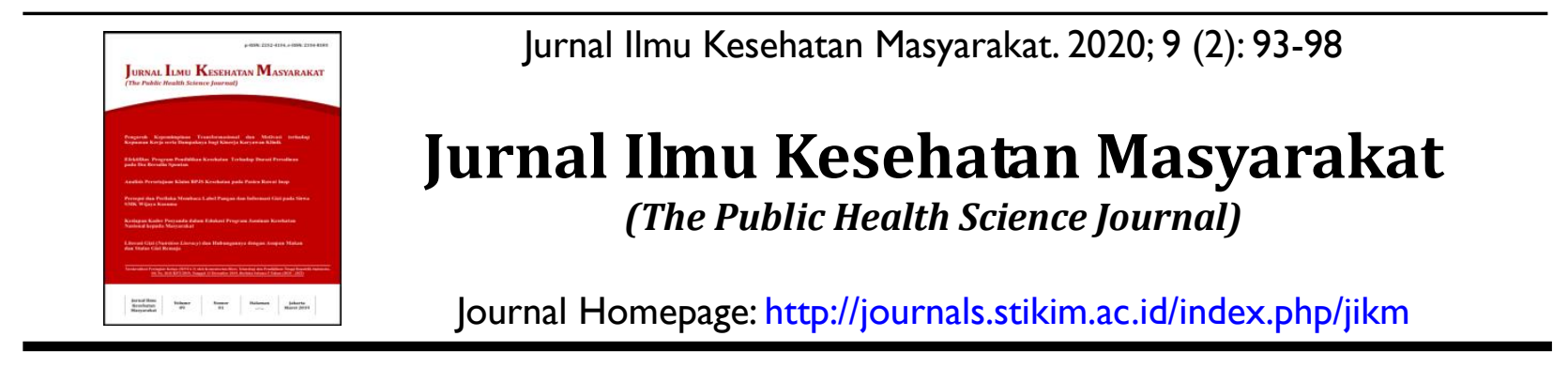

\title{
Hubungan Asupan Gizi dengan Kejadian Premenstrual Syndrome
}

\author{
Kartika Estiani ${ }^{1}$, Kusharisupeni Djokosujono ${ }^{2}$ \\ 1,2Departemen Gizi Kesehatan Masyarakat, Fakultas Kesehatan Masyarakat Universitas Indonesia, \\ Gedung F Lantai 2 Kampus Baru UI Depok 16424, Indonesia \\ Email: 'estianikartika@gmail.com, 2kusharisupeni@gmail.com
}

\begin{abstract}
Abstrak
Premenstrual Syndrome (PMS) adalah kumpulan gejala fisik, psikologis, dan emosional yang terkait dengan siklus menstruasi yang biasanya terjadi 7- 14 hari sebelum periode menstruasi dan menghilang ketika menstruasi dimulai. Gejala yang muncul dapat mengganggu aktivitas. Salah satu faktor penyebab PMS adalah asupan gizi. Tujuan dari penelitian ini yaitu menganalisis hubungan antara asupan gizi dengan kejadian PMS pada siswi SMA pada tahun 20I7. Penelitian ini menggunakan studi cross sectional dengan pendekatan kuantitatif. Pengumpulan data menggunakan formulir estimated food records 2x24 jam dan kuesioner Shortened Premenstrual Assessment Form untuk mendapatkan variabel PMS. Data dianalisis menggunakan uji regresi logistik. Hasil analisis multivariat menunjukkan empat variabel yang secara signifikan terkait dengan PMS yaitu asupan lemak $(P v=0,047 ; O R=0,680)$, karbohidrat $(P v=0,040 ; O R=0,339)$, serat $(\mathrm{Pv}=0,0 \mathrm{I}$; $\mathrm{OR}=-0,0005)$, dan piridoksin $(\mathrm{Pv}=0,079 ; \mathrm{OR}=0,7 \mathrm{I})$. Asupan piridoksin adalah variabel paling protektif terkait $P M S$ dengan $O R=0,7$ I 7. Analisis ini menghasilkan $O R<I$ artinya asupan lemak, karbohidrat, serat, dan piridoksin merupakan faktor protektif sehingga dapat mengurangi risiko kejadian PMS. Kesimpulan dari penelitian ini adalah PMS dapat terjadi jika siswi SMA tidak cukup asupan lemak, karbohidrat, serat, dan piridoksin. Oleh karena itu, siswi SMA perlu meningkatkan asupan makanan yang mengandung lemak, karbohidrat, serat, dan piridoksin sesuai kebutuhan gizi. Kata Kunci : Asupan gizi, premenstrual syndrome, siswi SMA
\end{abstract}

\begin{abstract}
Premenstrual Syndrome (PMS) consists of physical, psychological, and emotional symptoms associated with menstrual cycle which usually occurs 7-I 4 days before the menstrual period and disappears when menstruation begins. The symptoms can even cause interference activities. Nutrition intake is one of the factors causing PMS. The purpose of this study was to analyze the relationship between nutrition intake with PMS in Senior High Schoolgirls. This study uses a cross sectional study with a quantitative approach. Data collection used the $2 \times 24$ hour Estimated Food Records form and the Shortened Premenstrual Assessment Form, analyzed by logistic regression. The results of multivariate analysis found four variables that were significantly related to $P M S($ fat $(P v=0,047$; $O R=0,680)$, carbohydrate $(P v=0,040 ; O R=0,339)$, fiber $(P v=0,010 ; O R=-0,0005)$, and pyridoxine $(P v=0,079 ; O R=0,7 / 7))$. Pyridoxine intake is the most protective variable associated with premenstrual syndrome $O R=0,7$ I 7. This analysis resulted $O R<I$ means that intake of fat, carbohydrate, fiber, and pyridoxine is a protective factor, can reduce the risk of PMS. The conclusion is the schoolgirls can get the PMS if they had low intake of fat, carbohydrate, fiber, and pyridoxine. Therefore, schoolgirls need to increase the intake of foods containing fat, carbohydrate, fiber, and pyridoxine according to their nutritional needs.
\end{abstract}

Keywords: Nutrition intake, premenstrual syndrome, senior high school students 


\section{Pendahuluan}

Premenstrual Syndrome (PMS) adalah suatu kondisi yang ditandai dengan gejala fisik, perilaku dan emosi yang terjadi berulang kali dalam fase luteal (7-14 hari) dari siklus menstruasi yang dapat mengganggu rutinitas sehari-hari. ${ }^{1-4}$ Perasaan sedih dan tidak antusias, mudah tersinggung, nyeri pelvis dan persendian, sakit perut, perasaan tertekan, kewalahan dalam mengahadapi masalah, nyeri payudara, perut kembung, kenaikan berat badan, dan edema adalah gejala PMS. ${ }^{5}$ Hampir $75 \%$ wanita usia subur di seluruh dunia memiliki pengalaman PMS dan frekuensi gejala PMS pada wanita Indonesia adalah $80-90 \% .^{6}$ PMS memiliki keterkaitan dengan absensi di sekolah pada anak-anak sekolah. $^{7}$

Asupan energi dan zat gizi dari pangan yang dikonsumsi remaja, berpengaruh terhadap terjadinya PMS. $^{8}$ Pada fase pramenstruasi, terjadi peningkatan asupan lemak, karbohidrat dan gula, serta penurunan asupan protein. ${ }^{9}$ Upaya untuk mengatasi gejala PMS, diet yang disarankan adalah mengurangi asupan karbohidrat sederhana dan menambah asupan karbohidrat kompleks seperti serat. ${ }^{10}$ Karbohidrat dapat meredakan gejala PMS karena berperan dalam meningkatkan kadar gula darah sehingga tubuh menghambat hormon adrenalin yang menghentikan efektivitas hormon progesteron. ${ }^{11}$ Mengonsumsi makanan rendah lemak jenuh juga mengurangi keluhan nyeri pada perut dan pembengkakan pada pasien dengan gejala PMS. ${ }^{11}$ Wanita yang mengalami PMS lebih banyak mengonsumsi karbohidrat dibandingkan dengan mengonsumsi protein pada masa pramesntruasi. ${ }^{12}$ Selain itu, vitamin $\mathrm{B}$ dan kalsium dapat mengurangi risiko terjadinya PMS. $^{13,14}$ Tujuan dari penelitian ini yaitu menganalisis hubungan antara asupan gizi dengan kejadian PMS pada siswi SMA.

\section{Metode}

Penelitian ini adalah penelitian observasional tanpa intervensi kepada responden. Desain penelitian yang digunakan adalah cross sectional, yang dilakukan pada bulan April hingga Agustus 2017. Sampel sebanyak 99 orang merupakan siswi SMA di SMAN 4 Surabaya berusia 15-18 tahun yang sudah menstruasi. Penentuan sampel menggunakan metode cluster random sampling berdasarkan kelas. Dari total 9 kelas dilakukan pemilihan secara acak dan mendapatkan 5 kelas untuk memenuhi jumlah sampel yang dibutuhkan. Kelas yang terpilih terdiri dari XI MIA 4, XI MIA 5, XI MIA 6, XI MIA 7, dan XI IIS 2.

Data diperoleh dari kuesioner Shortened Premenstrual Assessment Form (SPAF) yang berisi 10 gejala yang sering dirasakan oleh wanita saat menstruasi, serta formulir estimated food records $2 \times 24$ jam yang disertakan dengan panduan cara pengisian formulir. Pada kuesioner SPAF yang berisi 10 gejala yang sering dirasakan oleh wanita saat menstruasi. Gejala-gejala tersebut terdiri dari sedih dan tidak bersemangat, mudah tersinggung, sakit panggul dan nyeri sendi, nyeri perut, tertekan, kewalahan atas persoalan, nyeri payudara, perut kembung, peningkatan berat badan, adanya edema. Siswi dinyatakan memiliki gejala PMS jika mengalami setidaknya satu dari gejala PMS tersebut.

Data energi, karbohidrat, protein, lemak, serat, kalsium, dan piridoksin diperoleh berdasarkan pengaturan jenis dan jumlah makanan yang dikonsumsi siswi SMA pada waktu tertentu. Pengumpulan data dilakukan dengan menggunakan kuesioner estimated food records yang diisi oleh responden selama 24 jam sebanyak 2 kali pengukuran dengan hari yang tidak berturut-turut. Peneliti menentukan hari pencatatan yang bukan hari libur untuk menghindari dari asupan makanan yang tidak sesuai dengan kebiasaan. Responden sebelumnya telah diberi pengarahan tentang cara mengisi kuesioner estimated food records dan juga dilampirkan panduan mengenai cara pengisian kuesioner tersebut. Asupan energi, karbohidrat, protein, lemak, serat, kalsium, dan piridoksin dikategorikan tidak memadai jika hasil anlaisis dengan 
Nutrisurvey kurang dari Estimated Average Requirements (EAR). Kebutuhan dikategorikan cukup jika lebih dari sama dengan EAR. Nilai EAR diperoleh dari nilai AKG 2019 yang dikonversi menggunakan EAR. ${ }^{15}$ Nilai yang diperoleh adalah energi 1750 kkal, karbohidrat $250 \mathrm{~g}$, protein $54,2 \mathrm{~g}$, lemak 58,3 g, serat 24,2 g, kalsium $1000 \mathrm{mg}$, dan piridoksin $1 \mathrm{mg}$. EAR adalah perkiraan jumlah zat gizi yang diperlukan untuk memenuhi kriteria kecukupan spesifik setengah dari individu sehat dari usia, jenis kelaminm dan tahapan kehidupan tertentu.

Analisis data menggunakan analisis multivariat untuk menganalisis hubungan antara beberapa variabel. Langkah-langkah analisis multivariat dilakukan dengan seleksi bivariat (hasil bivariat dengan $\mathrm{p}$ value $<0,25$ masuk ke tahap multivariat), lalu dilakukan permodelan multivariat, uji interaksi, damn permodelan terakhir. ${ }^{16}$ Penelitian ini disetujui oleh Komisi Etika Fakultas Kesehatan Masyarakat Universitas Airlangga dengan nomor 192-KEPK.

\section{Hasil}

Distribusi frekuensi kejadian PMS, asupan gizi berupa energi, protein, lemak, karbohidrat, serat, kalsium, dan pridoksin adalah sebagai berikut dijelaskan pada tabel 1.

Hasil data mengenai asupan gizi, berdasarkan tabel 1 didapatkan bahwa mayoritas siswi SMA tidak cukup mengonsumsi energi, protein, karbohidrat, serat, dan kalsium. Hanya zat gizi lemak dan piridoksin yang dikonsumsi secara cukup oleh mayoritas siswi SMA. Berdasarkan data pada tabel 2, gejala yang dialami oleh mayoritas siswi adalah mudah tersinggung sebanyak 92,9\%dan gejala yang paling sedikit dialami oleh siswi adalah adanya edema sebanyak $57,6 \%$.

Berdasarkan tabel 3 faktor asupan gizi yang berhubungan dengan kejadian PMS pada siswi SMA adalah asupan lemak, karbohidrat dan serat. Selanjutnya dilakukan analisis multivariat dengan melakukan seleksi terhadap variabel yang akan masuk

ke dalam pemodelan multivariat. Dari hasil analisis bivariat terlihat bahwa variabel asupan lemak, karbohidrat, serat, dan piridoksin memiliki nilai $\mathrm{p}$ value $\leq 0,25$. Dengan demikian keempat variabel tersebut dilakukan analisis multivariate.

Tabel 1. Distribusi Frekuensi Kejadian PMS dan Asupan Gizi Siswi SMA di SMAN 4 Surabaya Tahun 2017

\begin{tabular}{llcc}
\hline \multicolumn{1}{c}{ Variabel } & \multicolumn{1}{c}{ Kategori } & n & \% \\
\hline Kejadian PMS & Tidak PMS & 44 & 44,4 \\
& PMS & 55 & 55,6 \\
Energi & Tidak Cukup & 59 & 59,6 \\
\multirow{4}{*}{ Protein } & Cukup & 40 & 40,4 \\
& Tidak Cukup & 54 & 54,5 \\
Lemak & Cukup & 45 & 45,5 \\
& Tidak Cukup & 40 & 40,4 \\
Karbohidrat & Cukup & 59 & 59,6 \\
& Tidak Cukup & 77 & 77,8 \\
Serat & Cukup & 22 & 22,2 \\
& Tidak Cukup & 95 & 96,0 \\
Kalsium & Cukup & 4 & 4,0 \\
& Tidak Cukup & 87 & 87,9 \\
Piridoksin (B6) & Cukup & 12 & 12,1 \\
& Tidak Cukup & 48 & 48,5 \\
& Cukup & 51 & 51,5 \\
\hline
\end{tabular}

Tabel 2. Distribusi Frekuensi Gejala

Premenstrual Syndrome yang Dialami Siswi SMA di SMAN 4 Surabaya Tahun 2017

\begin{tabular}{lllll}
\hline \multicolumn{2}{c}{ Gejala PMS } & Kategori & n & \% \\
\hline Sedih dan & Tidak & Ya & 85 & 85,9 \\
Bersemangat & & Tidak & 14 & 14,1 \\
Mudah Tersinggung & Ya & 92 & 92,9 \\
& & Tidak & 7 & 7,1 \\
Sakit Panggul & dan & Ya & 80 & 80,8 \\
Nyeri Sendi & & Tidak & 19 & 19,2 \\
Nyeri Perut & & Ya & 85 & 85,9 \\
& & Tidak & 14 & 14,1 \\
Merasa Tertekan & & Ya & 78 & 78,8 \\
& & Tidak & 21 & 21,2 \\
Kewalahan & atas & Ya & 75 & 75,8 \\
Persoalam & & Tidak & 24 & 24,2 \\
Nyeri Payudara & & Ya & 88 & 88,9 \\
& & Tidak & 11 & 11,1 \\
Perut Kembung & & Ya & 59 & 59,6 \\
& & Tidak & 40 & 40,4 \\
Peningkatan & Berat & Ya & 79 & 79,6 \\
Badan & & Tidak & 20 & 20,2 \\
Adanya Edema & & Ya & 57 & 57,6 \\
& & Tidak & 42 & 42,2 \\
\hline
\end{tabular}


2017

\begin{tabular}{|c|c|c|c|c|c|c|}
\hline \multirow{3}{*}{ Asupan zat gizi } & \multirow{3}{*}{ Kategori } & \multicolumn{4}{|c|}{ Kejadian PMS } & \multirow{3}{*}{ Pvalue } \\
\hline & & \multicolumn{2}{|c|}{ Tidak PMS } & \multicolumn{2}{|c|}{ PMS } & \\
\hline & & $\mathbf{n}$ & $\%$ & n & $\%$ & \\
\hline \multirow[t]{2}{*}{ Energi } & Tidak Cukup & 28 & 47,5 & 31 & 52,5 & 0,463 \\
\hline & Cukup & 16 & 40,0 & 24 & 50,0 & \\
\hline \multirow[t]{2}{*}{ Protein } & Tidak Cukup & 16 & 51,6 & 15 & 48,4 & 0,417 \\
\hline & Cukup & 28 & 41,2 & 40 & 58,8 & \\
\hline \multirow{2}{*}{ Lemak } & Tidak Cukup & 12 & 30,8 & 27 & 69,2 & $0,047 *$ \\
\hline & Cukup & 32 & 53,3 & 28 & 46,7 & \\
\hline \multirow[t]{2}{*}{ Karbohidrat } & Tidak Cukup & 18 & 34,0 & 35 & 66,0 & $0,040 *$ \\
\hline & Cukup & 26 & 56,5 & 20 & 43,5 & \\
\hline \multirow[t]{2}{*}{ Serat } & Tidak Cukup & 39 & 42,4 & 53 & 57,6 & $0,010 *$ \\
\hline & Cukup & 5 & 71,4 & 2 & 28,6 & \\
\hline \multirow[t]{2}{*}{ Kalsium } & Tidak Cukup & 37 & 42,5 & 50 & 57,5 & 0,303 \\
\hline & Cukup & 7 & 58,3 & 5 & 41,7 & \\
\hline \multirow[t]{2}{*}{ Piridoksin (B6) } & Tidak Cukup & 25 & 39,7 & 38 & 60,3 & 0,079 \\
\hline & Cukup & 19 & 52,8 & 17 & 47,2 & \\
\hline
\end{tabular}

Tabel 4. Hasil Uji Regresi Logistik Asupan Gizi dengan Kejadian PMS pada Siswi SMA di SMAN 4 Surabaya Tahun 2017

\begin{tabular}{lcccc}
\hline \multicolumn{1}{c}{ Variabel } & B & Pvalue & OR & 95\% CI \\
\hline Asupan Lemak & $-0,386$ & 0,047 & 0,680 & $0,242-1,909$ \\
Asupan Karbohidrat & $-1,080$ & 0,040 & 0,339 & $0,124-0,933$ \\
Asupan Serat & $-21,457$ & 0,010 & 0,0005 & 0,0005 \\
Asupan Piridoksin & $-0,332$ & 0,079 & 0,717 & $0,263-1,957$ \\
\hline
\end{tabular}

Hasil analisis multivariat didapatkan bahwa ada 4 variabel yang berhubungan signifikan dengan kejadian Premenstrual Syndrome yaitu asupan lemak, asupan karbohidrat, asupan serat, dan asupan piridoksin. Hasil analisis seluruhnya menunjukkan hasil $\mathrm{OR}<1$ artinya asupan lemak, karbohidrat, serat, dan piridoksin merupakan faktor protektif artinya asupan lemak, karbohidrat, serat, dan piridoksin dalam jumlah yang cukup dapat menurunkan risiko kejadian Premenstrual Syndrome.

\section{Pembahasan}

Hasil analisis data PMS menunjukkan bahwa mayoritas siswi SMA pernah mengalami gejala PMS, yaitu 55,6\%. Meskipun PMS tidak mengancam nyawa, tapi dapat mengurangi produktivitas dan kesehatan mental seorang wanita. ${ }^{17}$ Sebuah penelitian menunjukkan bahwa asupan tinggi lemak bepengaruh terhadap hormon steroid sehingga disarankan untuk mengonsumsi diet rendah lemak dan tinggi $\begin{array}{lrr}\text { karbohidrat } & \text { untuk } & \text { mengurangi } \\ \text { pembengkakan } & \text { pada } & \text { payudara. }\end{array}$ Mengonsumsi makanan rendah lemak dapat menurunkan keluhan nyeri perut dan pembengkakan pada penderita PMS. ${ }^{19}$ Anjuran asupan lemak untuk remaja putri usia 16-18 tahun adalah 82,1 g per hari. ${ }^{20}$

Karbohidrat berhubungan dengan kejadian PMS sejalan dengan penelitian yang menyatakan bahwa karbohidrat berpengaruh dalam memprediksi kejadian PMS. ${ }^{21}$ Untuk mengatasi gejala PMS, diet yang dianjurkan adalah mengurangi asupan karbohidrat sederhana dan meningkatkan asupan karbohidrat kompleks seperti serat. ${ }^{10}$ Karbohidrat dapat meringankan gejala PMS karena berperan dalam meningkatkan kadar gula darah sehingga tubuh menghambat hormon adrenalin yang menghentikan efektifitas hormon progesterone. ${ }^{19}$ Mengkonsumsi makanan rendah lemak dapat menurunkan keluhan nyeri perut dan pembengkakan pada penderita PMS. ${ }^{19}$

Serat memiliki fungsi penting dalam pola konsumsi. Asupan serat yang rendah 
dapat menyebabkan obesitas. $^{22}$ Setiap kenaikan $1 \mathrm{~kg} / \mathrm{m}^{2}$ IMT dikaitkan dengan peningkatan risiko PMS sebesar $3 \% .^{24}$ Menurut penelitian Nagata, konsumsi makanan berserat seperti sayuran dan buah-buahan dapat menurunkan keluhan PMS. ${ }^{25}$ Konsumsi makanan berserat seperti sayuran dan buah-buahan dapat menurunkan keluhan Premenstrual Syndrome. ${ }^{25}$

Dalam penelitian ini, piridoksin memiliki hubungan dengan terjadinya PMS. Hal tersebut sejalan dengan penelitian Soviana yang menyatakan bahwa adanya hubungan asupan piridoksin dengan PMS. ${ }^{26}$ Piridoksin berperan membentuk fosforilasi PLP (piridoksal fosfat) dan PMP (piridoksanin fosfat) sebagai koenzim terutama dalam transaminase, dekarboksilasi dan reaksi lain yang berkaitan dengan metabolisme protein. ${ }^{27}$ Selain itu, piridoksin juga membantu pembentukkan sel darah merah serta mempertahankan sistem saraf sehingga dapat menurunkan risiko kejadian PMS. ${ }^{28}$

Pada penelitian ini, energi, protein, dan kalsium tidak memiliki hubungan dengan terjadinya PMS. Hal ini sejalan dengan penelitian lain yang menyatakan bahwa tidak ada hubunngan antara asupan energi dan protein. ${ }^{8}$ Penelitian lain menunjukkan tidak adanya hubungan asupan kalsium dengan kejadian PMS. ${ }^{29}$ Tidak adanya hubungan energi, protein, dan kalsium dapat disebabkan karena sebagian besar responden memiliki asupan energi, protein, dan kalsium yang kurang berdasarkan hasil analisis food record $2 \times 24$ hours.

\section{Kesimpulan}

Hasil penelitian menunjukkan asupan gizi terutama lemak, karbohidrat, serat, dan piridoksin menjadi faktor protektif untuk mengurangi risiko PMS. Dalam upaya mencegah kejadian PMS, siswi SMA perlu meningkatkan asupan sesuai kebutuhan dengan prinsip gizi seimbang untuk mengurangi risiko mengalami gejala PMS.

\section{Daftar Pustaka}

1. O’Brien PM, Bäckström $\mathrm{T}$, Brown $\mathrm{C}$ et al. Towards a consensus on diagnostic criteria, measurement and trial design of the premenstrual disorders: the ISPMD Montreal consensus. Arch Women Ment Health 2011; 14: 13-21.

2. Sammon CJ, Nazareth I, Petersen I. Recording and treatment of premenstrual syndrome in UK general practice: a retrospective cohort study. BMJ Open 2016; 6: e010244.

3. Raval CM, Panchal BN, Tiwari DS, Vala AU, Bhatt RB. Prevalence of premenstrual syndrome and premenstrual dysphoric disorder among college students of Bhavnagar, Gujarat. Indian J Psychiatry 2016; 58: 164-70.

4. Nourjah P. Premenstrual Syndrome among Teacher Training University Students in Iran. $J$ Obstet Gynecol. 2008; 58(1): 49-52.

5. Allen SS, McBride CM, Pirie PL. The Shortened Premenstrual Assessment Form. J Reprod Med. 1991; 36(11): 769-72.

6. Pudiastuti RD. Fase Penting pada Wanita, Jakarta: Kompas Gramedia; 2012.

7. Arafa A, Saleh L, Shawky S. Association between Menstrual Disorders and School Absenteeism among Schoolgirls in South Egypt. International Int J Adolesc Med Health. 2019.

8. Utari D. Hubungan Asupan Gizi dengan Sindrom Pramenstruasi pada Remaja Putri di SMA Bina Insani Bogor. Skripsi. Institut Pertanian Bogor, 2013.

9. Cross GB, Marley J, Miles H, Willson K. Changes in Nutrient Intake During the Menstrual Cycle of Overweight Women with Premenstrual Syndrome. British J Nutr, 2001; 85: 475-482

10. Mayo JL. Premenstrual Syndrome: A Natural Approach to Management Applied. Nutritional Science Report, 1999; 5(6): 1-8.

11. Simon H. Premenstrual Syndrome. Associate Profesor of Medicine, Harvard Medical School: Physician, Massachusetts General Hospital. A.D.A.M. Inc, 2003.

12. Wurtman JJ, Brzezinzki A, Wurtman RJ, Laferrere B. Effect of Nutrient Intake on Premenstrual Depression. American J Obstetr Gynecol, 1989; 161(5): 1228-1234.

13. Chocano-Bedoya PO, Manson JE, Hankinson SE, Willett WC, Johnson SR, Chasan-Taber L, Ronnenberg AG, Bigelow C, Bertone-Johnson ER. Dietary B Vitamin Intake and Incident Premenstrual Syndrome. Am J Clin Nutr, 2011; 93(5): 1080-1086.

14. Bertone-Johnson ER, Hankinson SE, Bendich A, Johnson SR, Willett WC, Manson JE. Calcium and Vitamin D Intake and Risk of Incident Premenstrual Syndrome. Arch Intern Med, 2005; 165(!1): 1246-1252

15. Gibson RS. Principles of Nutrition Assessment, Ed ke-2. New York: Oxford University, 2005.

16. Hastono, S. P. Analisis Data pada Bidang Kesehatan. Depok: RajaGrafindo Persada, 2017

17. Bungasari SA. Gambaran Sindroma Prahaid pada Remaja. Jurnal e-Clinic (eCl). 2015; 3(1) 
18. Paath EF. Gizi dalam Kesehatan Reproduksi. Jakarta: Penerbit Buku Kedokteran EGC, 2004.

19. Simon H. Premenstrual syndrome. Associate Profesor of Medicine, Harvard Medical School: Physician, Massachusetts General Hospital. A.D.A.M. Inc. 2003

20. AKG. Permenkes RI No. 28 Tahun 2019 tentang Angka Kecukupan Gizi yang Dianjurkan bagi Masyarakat Indonesia. Jakarta: Menteri Kesehatan Republik Indonesia; 2019

21. Tanjung AS. Hubungan antara Asupan Zat Gizi dengan Kejadian Premenstrual Syndrome (PMS). Karya Tulis Ilmiah. Universtas Sebelas Maret; 2009.

22. Sofa IM. Kejadian Obesitas, Obesitas Sentral, dan Kelebihan Lemak Viseral pada Lansia Wanita. Amerta Nutr, 2018; pp 228-236

23. Apriany RE. Asupan Protein, Lemak Jenuh, Natrium, Serat dan IMT terkait dengan Tekanan Darah Pasien Hipertensi di RSUD Tugurejo Semarang. Journal of Nutrition College; 2012.

24. Johnson ERB, Hankinson SE, Willett WC,
Johnson SR, Manson JE. Adiposity and the Development of Premenstrual Syndrome. Journal Womens Health (Larchmt). 2010; 19(7)

25. Nagata C, Hirokawa K, Shimizu N, Shimizu H. Soy, Fat and Other Dietary Factor In Relaton To Prementrual Symptoms In Japans Women. International Journal of Obstetrics nd Gynecology. 2005. Vol 11, pp. 594-599.

26. Soviana E dan Putri AR. Hubungan Asupan Vitamin B6 dan Kalsium dengan Kejadian Sindrom Premenstruasi pada Siswi di SMAN Colomandu. The 5th Urecol Proceeding. 2017. p. 1588-94

27. Saryono dan Sejati W. Sindrom Pramenstruasi, Yogyakarta: Nuha Medika; 2009.

28. Laila NN. Buku Pintar Menstruasi, Yogyakarta: Buku Biru; 2011

29. Febriantini D. Hubungan Asupan Kalsium dengan Sindrom Pramenstruasi (PMS) pada Kelompok Remaja Putri Overweight di Kota Batu. Skripsi. Universitas Brawijaya, 2017. 